\title{
THE "GENERAL SCHOOL EDUCATION INTRODUCTORY ENGLISH CURRICULUM FOR GRADE 1 AND GRADE 2": A NEW INNOVATION IN FOREIGN LANGUAGE GENERAL SCHOOL EDUCATION IN VIETNAM
}

\author{
Hoang Van Van* \\ VNU University of Languages and International Studies, \\ Pham Van Dong, Cau Giay, Hanoi, Vietnam
}

Received 05 October 2019

Revised 12 March 2020; Accepted 20 July 2020

\begin{abstract}
This paper is concerned with a new innovation in foreign language general school education in Vietnam which has been attracting considerable attention from Vietnamese foreign language educators, foreign language teachers, and the general public - the General School Education Introductory English Curriculum for Grade 1 and Grade 2 issued in 2018 by the Ministry of Education of Vietnam. To highlight this important innovation, the paper attempts to address three main issues: (1) it will examine and clarify some of the most important aspects of the General School Education Introductory English Curriculum for Grade 1 and Grade 2; (2) it will present and discuss in some detail the contents in Tiếng Anh 1 (English 1) - a new English textbook developed in accordance with the General School Education Introductory English Curriculum for Grade 1 and Grade 2 by Vietnam National Publishing House in collaboration with Springer Nature Macmillan Education; and (3) it will outline and discuss some specific classroom methods and present a new procedure for teaching an activity/task to help teachers and pupils teach and learn English effectively.

Keywords: the General School Education Introductory English Curriculum for Grade 1 and Grade 2, English 1, effective classroom teaching methods, new procedure for teaching a language activity
\end{abstract}

\section{Introduction}

In the present-day world of increasing integration and globalization, English is naturally recognized as having an extremely important role. Starting from a collection of dialects spoken in the southern counties of England, after nearly four centuries the English language has expanded far beyond its nation, and has now become a lingua franca in

* Tel.: 84-946296999, Email: vanhv@vnu.edu.vn; vanhv.sdh@gmail.com two distinct but related senses: "international language" and "global language" (Halliday, 2017). English has been the most widely used language in literature, art, business, science, technology, media, diplomacy, tourism and many other areas of human activity. Recent studies on the situation of the teaching and learning of English in the world (e.g. Cheshire, 1996; Nunan, 2003; Eurydice, 2005, 2017; Shin and Scrandall, 2015; Hoang Van Van, 2016, 2019) have shown that in many countries and territories around the world a foreign language (principally English) is introduced 
into the primary school, and in some countries and territories English is even introduced into the pre-school (the kindergarten level).

In Vietnam, since Doi Moi (Renovation) which was initiated by the Communist Party of Vietnam in 1986, English has become the most important foreign language taught at all levels of learning nationwide. In 2008, the Prime Minister of the Socialist Republic of Vietnam issued Decision 1400 approving the national Project entitled Đề án dạy và học ngoại ngũ trong hệ thống giáo dục quốc dân giai đoan 2008-2020 (Teaching and Learning Foreign Languages in the National Education System Period 2008-2020) which states that at the general school education, English is a compulsory subject taught from grade 3 through to grade 12 . Since the end of 2010, the Ministry of Education and Training (MoET) (Bộ Giáo dục và Đào tạo, 2010a, 2012a, $2012 b$ ) has issued and piloted nationwide three English language curricula referred to respectively in Vietnamese as Chuoong trinh tiếng Anh thi điểm tiểu học (Pilot English Curriculum for Primary Schools in Vietnam), Chưong trình giáo dục phổ thông môn tiếng Anh thi điểm cấp trung hoc co sỏ (Pilot English Curriculum for Lower Secondary Schools in Vietnam), Chuoong trình giáo dục phổ thông môn tiếng Anh thi điểm cấp trung học phổ thông (Pilot English Curriculum for Upper Secondary Schools in Vietnam) (for details of these English pilot curricula, see Hoang Van Van, 2018). In 2018, MoET (Bộ Giáo dục và Đào tạo, 2018a) had the three pilot English language curricula combined into one unified English curriculum, and issued it under the title of Chuoong trình giáo dục phổ thông: Chưong trình môn tiếng Anh (General School Education Curriculum: English Curriculum). At the same time, in order to meet the ever increasing needs of learning English of early primary children, MoET (Bộ Giáo dục và Đào tạo, 2018b) issued a separate English language curriculum entitled Chưong trình giáo duc phổ thông làm quen tiếng Anh lớp 1 và lớp 2 (General School Education Introductory English Curriculum for Grade 1 and Grade 2). This is perhaps the first optional introductory English curriculum in the world issued at national level. "What are the main features of the General School Education Introductory English Curriculum for Grade 1 and Grade 2 ?", "How are the guidelines in the curriculum transformed into English textbooks for grade 1 and grade 2 children?", and "What possible method(s) should be suggested to teach English effectively to Vietnamese grade 1 and grade 2 pupils?" These questions will be addressed throughout this article. The article is organized around five sections. Following Section one which introduces and outlines the study, Section two examines and highlights some of the most important aspects of the General School Education Introductory English Curriculum for Grade 1 and Grade 2. Section three presents and discusses in some detail the contents in Tiếng Anh 1 (English 1) - a new English textbook developed in accordance with the General School Education Introductory English Curriculum for Grade 1 and Grade 2 by Vietnam National Publishing House in collaboration with Springer Nature Macmillan Education. Section four outlines some specific classroom methods and presents a new procedure for teaching an activity/task to help teachers teach English to grade 1 and grade 2 children effectively. Finally, Section five summarizes the main points explored in the paper, offering some ideas on how to achieve the goals of the General School Education Introductory English Curriculum for Grade 1 and Grade 2.

\section{The General School Education Introductory English Curriculum for Grade 1 and Grade 2}

The General School Education 
Introductory English Curriculum for Grade 1 and Grade 2 (hereafter shortened to the Curriculum) was promulgated by the Ministry of Education and Training via Circular No. 32, December 26, 2018. This is a major document all parts of which are central to our discussion, but for the purpose of this paper, we are focusing on four headings: (1) characteristics of the Curriculum, (2) principles for designing the Curriculum, (3) goal and objectives of the Curriculum, and (4) content of the Curriculum.

\subsection{Characteristics of the Curriculum}

The Curriculum is characterized by the following prominent features:

- It is an optional curriculum.

- Its aim is to familiarize pupils with very simple and basic or "introductory" English.

- It is a national level curriculum: it is issued by the Vietnamese Ministry of Education and Training. Some may notice that some other countries in the world have also introduced English in the early years of the primary level (grade 1 and grade 2), but no country seems to have issued a similar English optional curriculum at the national level as Vietnam.

- It is designed in connection with the General School Education English Curriculum - the 10-year curriculum in which English is taught as a compulsory subject from grade 3 through to grade 12 issued by the Ministry of Education and Training via Circular No. 32/2018/-TT-BGDĐT of December 26, 2018 (Bộ Giáo dục và Đào tạo [MoET], 2018b).

\subsection{Principles for designing the Curriculum}

The design of the Curriculum is based on the following principles:

- It should comply with the guidance on optional subjects as defined in the General School Education Curriculum promulgated by the Ministry of Education and Training via Circular No. 32/2018/-TT-BGDĐ of December 26, 2018 (Bộ giáo dục và Đào tạo [MoET], 2018a).

- It should be based on the theoretical and practical realities of teaching English as a foreign language, drawing on the achievements in teaching foreign languages to young children in the world as well as in Vietnam, and, in particular, taking into account social practices, economic conditions and cultural traditions of Vietnam, the background diversity of Vietnamese children in terms of regions, environments, and abilities.

- It should be communication-based, taking communicative competence as the goal of the teaching process, and language knowledge as a means to form and develop pupils' communication skills. In the initial stage of learning, it should give priority to oral skills, particularly the listening skill, while paying due attention to initial writing skills such as tracing and then writing alphabetical letters in words.

- It should be organized according to communicative competence development goals, language goals (which are seen as a means to form and develop communication skills), and themes and topics (which are familiar to pupils and allow for recycling and expanding in a spiral circle over the period of two years of learning to develop and strengthen children' communicative competence).

- It should be based on "centre design" principle, taking methods of teaching as the point of departure for setting the Curriculum's learning outcomes. Apart from this, it should take into account learners' factors (such as their psychological and physical characteristics, their learning styles, their time of exposure to English language), teachers' factors (such as their qualification, their current classroom teaching methods, their role in guiding pupil's learning), and the diverse teaching and 
learning conditions across Vietnam.

- One more principle which can be inferred from the design of the Curriculum is that it should ensure the continuity of curriculum between it and the General School Education English Curriculum (Bộ giáo dục và Đào tạo [MoET], 2018b).

\subsection{Goal and objectives of the Curriculum}

The overarching goal of the Curriculum is to provide Vietnamese grade 1 and grade 2 children with basic "introductory" or "crash-level" English. Through exploring and experiencing introductory English, pupils develop basic English communication skills in contexts suitable to their age level of thinking, their emotional and physiological ability, helping them feel confident when they enter grade 3 where they will learn English as a compulsory subject through to grade 12 , and gradually developing their love for the English language as a school subject.

To accomplish this overarching goal, the Curriculum sets 12 specific objectives which are stated on behavioural terms. Accordingly, on finishing the programme, pupils can:

- listen and recognize letters in the English alphabet;

- listen and recognize some basic sounds corresponding to the letters in the English alphabet;

- listen and understand numbers from 1 to 20 ;

- listen and understand simple words and phrases related to pupils' experience and activities in contexts;

- listen, understand, and give nonverbal responses in simple communication activities related to grade 1 and grade 2 children's experience;

- listen and understand simple English classroom instructions;

- listen, understand and give responses in English in simple and familiar question- and-answer situations;

- answer simple questions familiar with pupils' experience at word and very simple sentence level;

- give some simple and familiar English instructions when engaging in classroom communicative activities;

- recognize and read aloud very simple, concrete and familiar words and phrases;

- write some very simple words related to familiar topics;

- form a love for the English language as a school subject.

Based on the goal and objectives, the Curriculum outlines the requirements for grade 1 and grade 2 pupils in terms of the four skills of listening, speaking, reading, and writing.

On finishing grade 1, pupils can:

- repeat words, phrases, simple sentences, chants, and songs suitable to grade 1 pupils' level of thinking, their emotional and physiological ability, and their psychosocial skills;

- number 1 to 10 , and count them or give answers to simple questions relating to these numbers;

- recognize and name simple and concrete words related to the learned topics in specific contexts of communication;

- respond to questions in English in very simple question-and-answer situations;

- listen and understand nonverbal responses in simple conversations and use simple classroom commands;

- know how to use simple greeting and simple leave-taking expressions.

On finishing grade 2, pupils can:

- repeat simple phrases, simple sentences, chants, and songs suitable to grade 2 pupils' level of thinking, their emotional and physiological ability, and their psychosocial skills; 
- recognize and name concrete nouns and verbs related to the learned topics in specific contexts of communication;

- recognize numbers 11 to 20 , and count them or give answers to simple questions relating to these numbers;

- listen, understand and give simple feedback in English in similar and very simple question-and-answer situations;

- understand and give very simple classroom instructions which are longer and more complex than those learned in grade 1;

- give some familiar and simple commands when engaging in communicative activities in class, using more words and more complex grammatical structures than those learned in grade 1;

- answer simple questions and give oneor two-word answers in specific and familiar contexts.

\subsection{Content of the Curriculum}

The content of the Curriculum is organized around two main headings: General content and specific content.

\subsubsection{General content}

The general content of the Curriculum consists of three components: language content, language skills, and a list of themes:

Language content consists of three aspects: pronunciation or phonics, vocabulary, and grammatical structures which are respectively specified in the Curriculum as follows:

- Pronunciation: (Pupils) are introduced to some basic single or monophonic sounds: vowels, consonants (in initial and final word position), some letter(s) realizing the sound(s).

- Vocabulary: are introduced to simple words and phrases relating to people, things, and phenomena close to their daily experience in familiar topics and situations. The number of active words to be introduced ranges from 70 to 140 .

- Grammatical structure: are introduced to some simple grammatical structures, and are expected to be able to use them in familiar and very simple communicative situations.

Language skills include four aspects of speech: listening, speaking, reading, and writing which are respectively stated in behavioural terms as follows:

- Listening: (Pupils) can listen, understand, and answer very simple questions (using some very simple appropriate nonverbal expressions or gestures) at word level in simple classroom conversations and in familiar topics or situations; can listen, understand, and follow simple classroom instructions in English; and can understand simple words and phrases close to their experience in familiar contexts or topics within the recommended range of 70140 words.

- Speaking: can repeat simple words, phrases, and sentences; can sing chants and songs related to the topics suitable to the age of grade 1 and grade 2 children; can answer simple questions in familiar topics; can participate in simple communicative activities and language games; and can give some simple English instructions.

- Reading: can read simple words and sentences with the help of illustrative images; can listen to words and simple structures and read them along; and can recognize words and understand their meaning in the learned topics within the recommended range of 70140 words.

- Writing: can trace and write single (alphabetical) letters and words (at grade 1); and can write single letters, simple words, phrases, and sentences in specific contexts (at grade 2). 
List of Themes. The Curriculum recommended a list of 21 general themes (similar to "notions" in David Wilkin's (1976) terminology). This is a useful suggestion for textbook writers as they can base themselves on this list of themes to break it down into smaller and more specific topics for their textbook design. Details are provided in Table 1.

Table 1. List of themes recommended in the Curriculum
1. Colours
8. Daily activities
15. Fun activities
2. Animals
9. Classroom activities
16. Rooms in the house
3. Toys
10. School things
17. Fruit
4. School
11. Parts of the body
18. Food
5. Family
12. Days of the week
19. Emotions
6. Basic shapes
13. Clothes
20. Senses
7. Locations
14. Means of transport
21. Games

\subsubsection{Specific content}

Based on the list of themes, the Curriculum suggests specific contents which grade 1 and grade 2 children are required to learn. These include topics (which are derived from the list of themes), communicative competences which pupils need to learn in terms of the language skills of listening, speaking, reading, and writing, the number of sounds, of letters, of words, and of grammatical structures. Due to limited space, however, these components are not presented here. (For details, readers are referred to Bộ Giáo dục và Đào tạo [MoET], 2018c).

\section{English textbooks for grade 1 and grade 2}

Textbooks are an almost universal element in any form of teaching. For the majority of school teachers, textbooks serve as a peg on which teachers and students hang their teaching and learning (O’Neill, 1995; Hoang Van Van, 2012). For teachers of English at primary level, textbooks play an even much more important role (Rixon and Papp, 2018). They "provide structure and a syllabus for a programme (curriculum in our terminology); help standardize instruction; maintain quality; provide a variety of learning resources; are sufficient (in the sense of saving teachers' time, enabling them to devote time to teaching rather than material production); provide effective language models and input; and train teachers" (Richards, 2001: 254-55). They "offer a coherent syllabus, satisfactory language control, motivating texts, tapes and other accessories such as videotapes, CDROMS, extra resource material, and useful weblinks. (...). They come with detailed teacher's guides which not only provide procedure for the lesson in the student's book, but also offer suggestions and alternatives, extra activities and resources (Hammer, 2005: 304; 2017: 152-53). These are perhaps the reasons why when asked to provide comments about a curriculum, many EFL teachers often give responses in relation to a textbook without knowing that a textbook is just a realization of the curriculum. At present, Vietnam is exercising the policy of "one curriculum, multiple textbooks", and there are actually several sets of English textbooks in use in primary schools. In what follows, I shall be concerned only with the set of English textbooks developed for grade 1 and grade 2 children by authors of Vietnam Education Publishing House (VEPH) in 
collaboration with those of Springer Nature Macmillan Education (hereafter shortened to the VEPH-Macmillan set of textbooks). The VEPH-Macmillan set of textbooks has been trialled in a number of primary schools in Vietnam and has been well received for its pedagogy and resource design; its components comprising Sách họ sinh (Student's Books), Sách giáo viên (Teacher's Books), Sách bài tạp (Workbooks) CD-ROMS, and other supplementary learning resources.

Given that the time allocated for each of the grades in the Curriculum is very limited: 2 periods/per week, and 70 periods/per school year; given that English for grade 1 and grade 2 is an optional subject; and given that the aim of the Curriculum is to familiarize the children with very basic "introductory" English, the following questions were raised for consideration when developing the set of textbooks:

- How much language content (pronunciation, vocabulary, and structure) should be selected for the design of the textbooks to accomplish the Curriculum's goal?

- What level of English in terms of language skills is needed in the design of the textbooks to accomplish the Curriculum's goals?

- How should the language content and language skills be integrated into the topics of the textbooks to accomplish the Curriculum's goal?

- How much intercultural content (Vietnamese, English-speaking, and international culture) is needed, and how should it be integrated into the design of the textbooks to accomplish the Curriculum's goal?

- How should the textbooks be designed to help teachers and pupils achieve the Curriculum's goal?

As Tiếng Anh 2 has not yet come out, we will address these questions in relation to Tiếng Anh 1 - Sách họ sinh (English 1 - Student's Book), Tiếng Anh 1 - Sách giáo viên (English 1 - Teacher's Book), and Tiếng Anh 1 - Sách bài tập (English 1 - Workbook) - an intercultural collaboration product codeveloped by VEPH and Springer Nature Macmillan Education (Hoang Van Van et al., 2019a, 2019b, 2019c).

\subsection{English 1 - Student's Book}

\section{Aim of writing}

English 1 - Student's Book is designed in accordance with the General School Education Introductory English Curriculum for Grade 1 and Grade 2. Its aim is to provide grade 1 children with basic English in terms of knowledge and skills so that they will be confident to continue learning English at grade 2 through to grade 12.

Principles of writing

The design of English 1 - Student's Book is based on the following principles:

- It should be designed in accordance with the General School Education Introductory English Curriculum for Grade 1 and Grade 2 in terms of time frame, content of teaching, method of teaching, and method of testing;
- It should place English in relation to other subjects offered in grade 1, especially the subject of Vietnamese (children's mother tongue), taking this as a basis for selecting, grading, and sequencing the content (linguistic knowledge and 
communication skills) of the textbook;

- It should help grade 1 pupils familiarize with "introductory English" in the proper sense of the term at the beginning stage of the primary education;

- It should ensure the continuity of Tiếng Anh 1 (English 1) with Tiếng Anh 2 (English 2 ), and with the rest of the 10-year English textbook series from grade 3 through to grade 12 in the Vietnamese general school education;

- It should balance intercultural features in its design so as to initially familiarize children with the world's cultural diversity.

Approach to writing English 1-Student's Book

The main approach to writing English 1 - Student's Book is communication, taking as centre pupils' learning activities, laying emphasis on pupils' formation of English communication skills through simple interactions in contexts, helping them acquire oral English in the earlier stage of language learning. At the start of the course, particular emphasis is placed on listening and speaking (through repeating, chanting, singing), with due attention being paid to pupils' ability to trace and then write alphabetical letters in words.

The main approach to organizing the contents of English 1 - Student's Book is audio-lingual and audio-visual presented in words and simple structures context. The audio-lingual and audio-visual materials and structural patterns are selected, graded, and sequenced in accordance with the selected topics and are presented in colours to facilitate pupils" "absorption" of the language.

\section{Content of English 1 - Student's Book}

Linguistic content: English 1 - Student's Book focuses on:

\begin{tabular}{|l|l|}
\hline Pronunciation: & $\begin{array}{l}16 \text { single sounds, including } 11 \text { consonants and } 5 \text { vowels: } b, c, a, d, i, e, g, h, o, \\
m, u, l, n, t, f, w .\end{array}$ \\
\hline Vocabulary: & $\begin{array}{l}\text { 64 basic productive words, including verbs, nouns (singular and plural), pronouns, } \\
\text { numbers, adjectives, etc. These are words indicating objects, phenomena, and } \\
\text { events relating to situations and topics familiar to pupils' experience. }\end{array}$ \\
\hline Structure: & $\begin{array}{l}\text { Simple and basic sentence structures with the verb be, the modal verb can, and } \\
\text { with other verbs familiar to pupils' experience such as have, run, see, touch } \\
\text { used in the present simple, the present continuous, and the imperative mood. }\end{array}$ \\
\hline
\end{tabular}

Language skills: Drawing on the Curriculum 's guidelines, the textbook sets the following language skill requirements. On finishing grade 1, pupils can:

\begin{tabular}{|l|l|}
\hline Listening: & $\begin{array}{l}\text { listen and recognize letters corresponding to } 16 \text { selected single sounds; } \\
\text { listen and repeat words and phrases, and words and phrases in simple chants and songs; } \\
\text { listen, understand, and give nonverbal feedback in simple communicative situations; } \\
\text { listen, understand, and give very simple classroom instructions; } \\
\text { listen and understand words and phrases related to familiar topics; } \\
\text { listen, recognize, and pronounce learned vowels and initial and final consonants; } \\
\text { listen, understand, and count numbers from } 1 \text { to } 10 .\end{array}$ \\
\hline Speaking & $\begin{array}{l}\text { ask and answer simple questions, using words or phrases in very simple sentences } \\
\text { about school things, toys, colours, numbers, names of family members, etc.; } \\
\text { name people and simple concrete objects with the help of images; } \\
\text { sing chants and songs to consolidate pronunciation, stress, rhythm, and intonation; }\end{array}$ \\
\hline
\end{tabular}




\begin{tabular}{|l|l|}
\hline Reading: & $\begin{array}{l}\text { read aloud words and simple phrases; } \\
\text { sing simple chants; } \\
\text { sing simple songs; } \\
\text { read and understand very simple stories. }\end{array}$ \\
\hline Writing: & $\begin{array}{l}\text { trace alphabetical letters; } \\
\text { trace alphabetical letters in words; } \\
\text { write alphabetical letters in words; } \\
\text { write words in phrases. }\end{array}$ \\
\hline
\end{tabular}

Structure of English 1 - Student's Book

English 1 - Student's Book includes 16 topics/units, 4 fun time sections, and 4 review units. The 16 topics/units have been selected to provide relevant topics that young Vietnamese children can relate to and engage with, both in and outside of classroom. Vietnamese characters (e.g. Ba, Nam, Hoa, Nam, etc.) in the textbook provide children a sense of familiarity and friendliness, and support them in exploring these topics in English. And overseas characters (e.g. Bill, Ben, Lucy, Phil, Sue, etc.) offer pupils new and different insights, and encourage their interest in discovering more of the wider world. Specific design of the 14 units, 4 fun times, and 4 reviews in English 1 - Student's Book is displayed in Table 2.

Table 2. Structure of English 1 - Student's Book

\begin{tabular}{llll}
\hline Unit 1 & In the school playground & Unit 9 & In the shop \\
\hline Unit 2 & In the dining room & Unit 10 & At the zoo \\
\hline Unit 3 & Fun time 1 & Fun time 3 \\
\hline Unit 4 & At the street market & Unit 11 & At the bus stop \\
\hline & Review 1 & Unit 12 & At the lake \\
\hline Unit 5 & At the fish and chip shop & Unit 13 & In the school canteen \\
\hline Unit 6 & In the classroom & Unit 14 & In the toy shop \\
\hline & Fun time 2 & & Fun time 4 \\
\hline Unit 7 & In the garden & Unit 15 & At the football match \\
\hline Unit 8 & In the park & Unit 16 & At home \\
\hline & Review 2 & Review 4
\end{tabular}

Structure of a unit in English 1 - Student's Book

Each unit in English 1 - Student's Book contains three individual lessons. Each lesson provides material for one teaching period (equating to thirty five minutes), in which language content and language skills are developed through warm-up activities, presentation, practice, application, and selfassessment/check.
Each unit in English 1 - Student's Book has a logical progression of activities, and clear and concise instructions which guide children through to their completion. These activities also help develop coordination, critical thinking and cooperative learning skills, as pupils learn to understand and use English in both its spoken and written forms.

Phonics is presented systematically throughout the units, helping pupils relate 
sounds to letters (symbols) in words, at the same time initially familiarizing them with word stress, rhythm and intonation in English through singing short chants and short songs.
The structure of a unit and the activities of each of the three lessons in the unit are represented in some detail below.

\section{Lesson 1}

Lesson 1 aims to familiarize pupils with the topic of the unit. Opening the Student's Book on Page 6, for example, pupils can see the number of the unit (Unit 1) and its title (In the school playground). Under these headings is a whole-page picture of a school scene setting the context for the lesson. In the picture pupils can see two boys playing with a ball, a girl reading a book under a big tree, and a bike standing next to a bed of flowers. Pupils can also see four words with the initial letter (in upper or lower case) " $\mathrm{B} / \mathrm{b}$ " highlighted in red: ball, Bill, book, and bike. Lesson 1 consists of two activities or tasks: Listen and repeat and Point and say.

The Listen and Repeat activity is intended to introduce pupils to the sound $/ \mathrm{b} /$ represented by the upper case letter B or the lower case $b$ in the picture and the four words presented in the context of the picture (from top): ball, Bill, book, and bike. Pupils are required to listen to the target sound and repeat it in in the words.

The Point and say activity aims to help pupils pronounce correctly the target sound in the four-word context. By pointing at the letter highlighted in red and say the words in which the target sound occurs, pupils are initially familiarized with the sound-symbol association, and the meaning of the words in context.

\section{Lesson 2}

Lesson 2 aims to strengthen the contents pupils have learnt in Lesson 1. It includes three activities: Listen and chant, Listen and tick, and Look and trace/Look, trace and write.

The Listen and chant activity is intended to strengthen pupils' pronunciation accuracy of the target sound $/ \mathrm{b} /$ in association with the letter $\mathrm{B} / \mathrm{b}$ by listening first and then chant. Through this activity, pupils can also be familiarized with English stress, rhythm and intonation in authentic context.

The Listen and tick activity is intended to initially introduce pupils to listening skill. They are given two pictures; each contains two objects (representing two words they have learned). Pupils listen to the recording and give a tick to the correct answer.

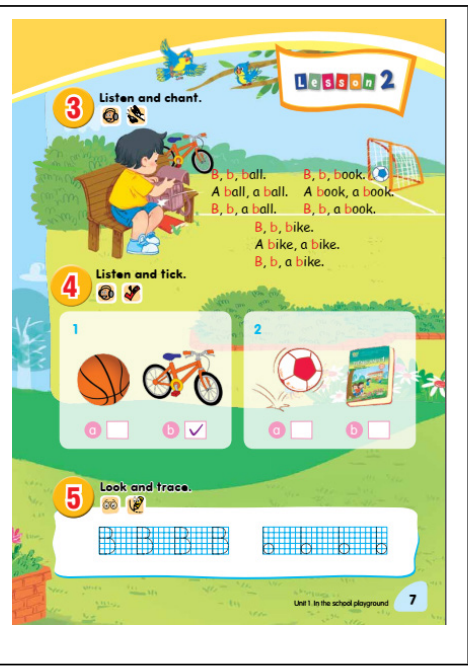

The Look and trace/Look, trace and write activity aims to develop pupils' ability to write alphabetical letters in words. It is designed into three separate stages to suit pupils' 
writing ability development: Look and trace is designed for the first stage (semester 1 of grade 1); Look, trace and write, for the second stage (semester 2 of grade 1); and Look and write, for the third stage (both semester 1 and semester 2 of grade 2).

\section{Lesson 3}

Lesson 3 aims to familiarize pupils with simple interactive English. It consists of three activities: Listen and repeat, Let's talk, and Let's sing.

The Listen and repeat activity aims to familiarize pupils with simple "seeded" forms of greeting (greeting and introducing oneself), and leave-taking (saying good bye to someone) in English. Pupils listen to the recording and repeat these forms (e.g. Hi, I'm Bill and Bye, Bill).

The Let's talk activity comes after the Listen and repeat. It aims to initially develop pupils' ability to speak English. Pupils use the same "seeded" forms of greeting and leave-taking; fill the blank the name of someone they have chosen at will and practise greeting and leave-taking with each other.

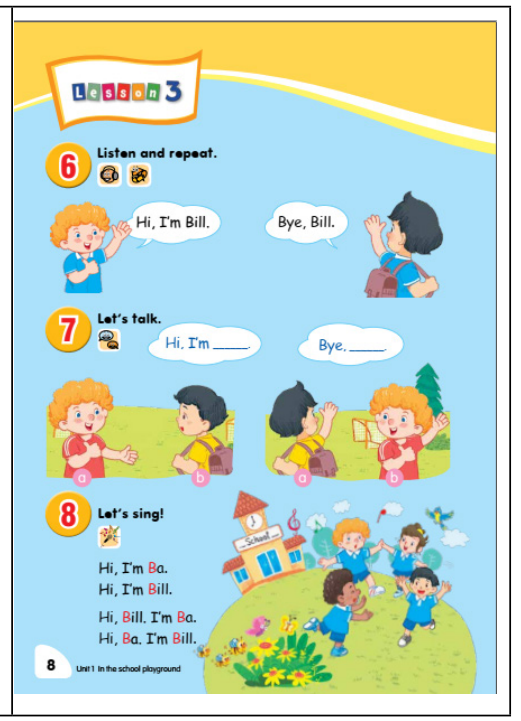

The Let's sing activity consists of a very simple English song. Its aim is to help pupils consolidate the sound-symbol association, the words, the phrases, and the structures they have been introduced in the previous seven activities. At the same time, this activity is intended to further consolidate pupils' pronunciation of the learned sound, and to have a sense of English rhythm and intonation as they sing along with actions such as dancing, jumping, or hopping.

Fun time

The Fun time section is designed after pupils have finished two learning units. It consists of two lessons.

Lesson 1 consists of two activities: Find/Match and circle. Then say and Let's play.

The Find/Match and circle. Then say activity aims to help pupils revise the words they have learned. They are given a word search with the pictures representing the learned words around. Their task is to find the words, match them with the pictures, and then say them aloud.

The Let's play activity aims to help pupils revise the sound-symbol associations they have learned through playing a game such as "Simon says", "Slap the board", etc.

\section{Fun time 2}

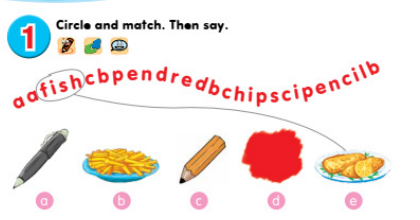

(2) Lots play.

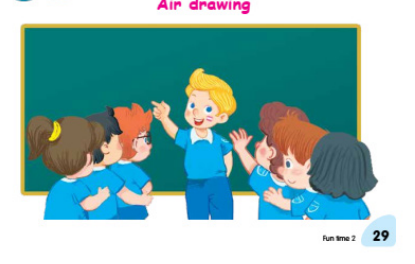

Lesson 2 is also organized into two activities: Read and tick. Then colour and say and Let's play.

The Read and tick. Then colour and say activity aims to help pupils identify the words they have learned from the pictures, then colour them, and say them aloud.

The Let's play activity aims to help pupils revise the structures they have learned through playing a game such as "A happy circle", "Air drawing", etc. 


\section{Review}

The Review unit is designed after pupils have finished four learning units. It aims to help pupils revise the sound-symbol association and the words they have learned through a diversity of activities. A Review unit generally consists of seven activities which can be delivered in three lessons.

Lesson 1 is a very simple dialogue between two young English characters: Phil and Sue. Their dialogue is about the words pupils have learned. This lesson is designed into two activities: Listen and repeat and

\section{Look and circle.}

The Listen and repeat activity requires pupils to listen to the dialogue between Phil and Sue and repeat what they said.

The Look and circle activity aims to develop pupils' exploratory ability. Pupils are asked to look at the pictures and find the corresponding words from the list of the words which Phil and Sue said in their dialogue, then circle the correct ones.

Lesson 2 and Lesson 3 aim to initially develop pupils' ability to self-evaluate or selfcheck their progress. These lessons consist of five activities: Listen and tick, Listen and circle, Listen and tick or cross, Read and tick, and Colour, write and say.

The Listen and tick activity aims to develop pupils' listening ability. They are asked to listen to the words from the audio CD and tick the correct boxes.

The Listen and circle activity aims to develop pupils' listening ability. They are asked to listen to the sounds from the audio CD and circle the correct letters representing the sounds.

The Listen and tick or cross activity aims to develop pupils' listening ability. They are asked to listen to the words from the audio $\mathrm{CD}$ and tick or cross the correct boxes.

The Read and tick activity aims to develop pupils' initial reading ability. They are asked to read the words, look at the pictures, and then tick the correct boxes.
The Colour, write and say activity aims to consolidate pupils' alphabet letter writing ability. They are asked to colour the words, write the intended letter in the words, and then say them aloud.

\subsection{English 1 - Teacher's Book}

The Introduction part consists of four sections. Following Section one which provides a brief introduction to English 1 Student's Book, Section two is concerned with a description of a learning unit in English 1 - Student's Book. Section three provides guidelines for teaching unit activities. And Section four includes some suggested common classroom instructions and expressions.

The Guidelines for teaching Units, Fun times, and Reviews part provides teachers with detailed guidance on how to teach the sixteen learning units, four fun time sections, and four review units. Central to grade 1 teaching methodology is the procedure of G-I-P-O (detail of which will be presented in 
Section 4.4.2 below). Teachers are advised to use this procedure in teaching and in preparing their lesson plans. For the diversity of teaching and learning contexts, it is recommended that teachers employ the procedure flexibly so as to teach their pupils effectively.

English 1 - Teacher's Book is written in English. In addition to the instructions for individual lessons, it provides teachers with English language support and in-classroom management guidance. It is written in simple English so that teachers can grasp the ideas of the Student's Book and use the Teacher's Book effectively.

The guidelines suggested in English 1 - Teacher's Book are based on the learning-centred approach in an effort to help teachers engage their pupils in interpersonal communication activities, and promote their creative learning potential.

Structure of English 1 - Teacher's Book

English 1 - Teacher's Book is organized into two main parts. Part I is Introduction, and Part II - Guidelines for teaching Units, Fun times, and Reviews.

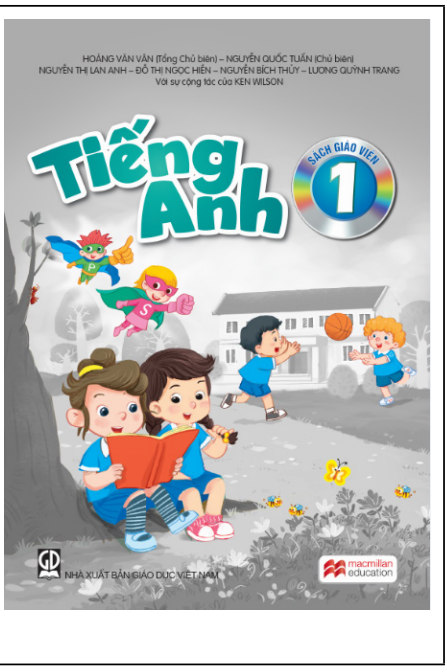

In order to maximize access to the content, together with the Student's Book, the Workbook and other supplementary learning resources, the Teacher's Book is offered online. It is hosted on a secure website, with password protection for digital management (for detail, readers are referred to sachmem.vn).

\subsection{English 1 - Workbook}

English 1-Workbook provides further reinforcement of the content in English 1 - Student's Book. The activities in the Workbook are designed to be attractive and engaging so that children can review the learned content in an enjoyable and memorable way. Clear instructions and the systematically- organized format in which these activities are presented ensure that the Workbook can be used easily outside the classroom. Apart from these, the Workbook contains some allowable extension of knowledge and skills to encourage pupils to learn more English.

The content of the Workbook is designed according to the sixteen learning units in the Student's Book. A unit in the Workbook includes seven activities: (1) Look and match, (2) Listen and circle, (3) Look and trace, (4) Look and write. Then say, (5) Read and match, (6) Game, and (7) Project.

The Look and match activity aims to help pupils revise the meaning of the words they have learned. They are required to look at the words and match them with the correct pictures.

- The Listen and circle activity aims to help pupils reinforce listening skill. They are 
required to listen to the audio $\mathrm{CD}$ and circle the correct words they hear.

- The Look and trace activity aims to consolidate pupils' initial writing (tracing) skill. They are required to look at the broken line letters and then trace them.

- The Look and write. Then say activity aims to consolidate pupils' writing skill. They are required to write the learned letter in the blank of the learned words, and then say the words aloud.

- The Read and match activity aims to consolidate pupils' reading skill. They are required to read the words they have learned in the "seeded" structures, and then match them with the correct pictures.

- The Game activity aims to reinforce pupils' vocabulary, develop their initial reading and speaking skills through creative and enjoyable activities such as "Do the puzzle", "Point to the difference. Then say", etc.

- Each unit of the Workbook ends with a Project. This activity aims to help pupils (i) revise the sound and the letter in the words they have learned from the learning unit, and (ii) to encourage pupils' creativeness in a real and engaging context such as "Trace the apple, the bag, the can, and the hat. Then point and say", "Find the stickers. Stick the desk, the dog, the door and the duck. Then point and say", etc.

\section{How to teach English to grade 1 and grade 2 children}

\subsection{Characteristics of grade 1 and grade 2 children}

Researchers and second/foreign language teaching methodologists (e.g. Lenneberg, 1967; Stern 1967; Rivers, 1970; Broughton et al, 1978; Brown, 2000; Moon, 2005; Cameron, 2011; Wendy, Scott and Ytreberg, 2011; Ur, 2012; Fernández and Cairns, 2015; Shin and Scrandall, 2015) have suggested numerous characteristics of young second/foreign language learners. The following observations seem to be relevant to Vietnamese learners of six- and seven-years old:

- They are physically active.

- They understand meaning from what they see and hear.

- They have relatively short concentration and attention span.

- They can understand direct interaction between people.

- They like to play, sing, and mime.

- They understand situations faster than they understand the language being used.

- They are less aware of language forms and the possibility of making mistakes in these forms.

- They use and accept language more unconsciously.

- They can mimic very well.

- They do not have difficulty in pronouncing foreign language sounds, and in imitating rhythmic and intonation patterns.

- They are ready to form small groups to do an activity together.

\subsection{Factors affecting grade 1 and grade 2} children's learning of English

The following factors may be said to affect Vietnamese six- and seven-years old children's learning English:

- They are enthusiastic and lively while doing things, but can be very likely to lose interest.

- English is an optional subject.

- The amount of experience of English given to them is extremely limited: 2 periods per week, 70 periods per year.

- English is a foreign language; the language of their daily communication is Vietnamese.

- The number of pupils per class is very large, usually over 40 per class; in some schools and localities, the number of pupils per class is even larger: over 50 or 60 . 
- When children start to learn English they are already fluent in oral Vietnamese: they already can use in their speech the Vietnamese sounds which we call phonemes such as $/ \mathrm{i} /, / \mathrm{a} /, / \mathrm{n} /, / \mathrm{m} /$, etc.; they already can combine those phonemes to form what we call words to refer to things/objects which we call nouns such as quả táo (apple), cái bàn (table), xe ca (car), túi xách (bag), qualities which we call adjectives such as to (big), cao (tall), lớn (rộng), vuông (square), tròn (round), dài (long), ngắn (short), đẹp (beautiful), xấu (ugly), actions and states which we call verbs such as đi (go), chạy (run/move), hát (sing), múa (dance), etc.; they already can combine objects, qualities, actions into longer chunks which we call sentences such as Có một chiếc xe to đang chạy trên đuròng (There is a big truck moving on the road); they already can use these longer chunks to state, to negate, to ask, to answer, and even to argue with others in appropriate contexts of use. In short, when pupils start learning English, they can express orally in Vietnamese what they are doing without attending a formal class. When they go to school, they learn formally what has been referred to as "literacy": they learn how to read and write by first relating the spelling forms (which they are taught formally) to the sound forms (which they have already acquired informally) of Vietnamese; and then they learn how to write and read the spelling-sound forms on the page to produce and comprehend meaning. In contrast, when pupils start to learn English, they know nothing about the language both in its spoken and written forms; and they have to learn all things concerning these forms at the same time.

- Unlike countries of Kachru's (1985) "Outer Circle" where the learning of English takes place in both "natural environment" (one in which students can learn and acquire
English both in and outside classroom) and "artificial environment" (one in which students learn English in classroom), the children's learning of English in Vietnam takes place in "artificial environment" which is often a very acquisition-poor environment.

- Children in urban and affluent areas often receive more attention and encouragement to learn English from parents than those in rural, remote and isolated areas.

- Teachers are recruited on a part-time basis; most of them are untrained in classroom methods and techniques of teaching English as a foreign language to younger learners.

\subsection{Some suggested classroom methods of teaching English to grade 1 and grade 2 children}

The world is replete with approaches to and methods of "language teaching" (one of the most slippery terms for the practical EFL teacher). If one attempts a quick search into books and reference materials in what is commonly referred to as "language teaching libraries" published in English, one can find numerous of them such as grammar-translation method, audio-lingual method, direct method, reading method, total physical response, silent way, suggestopedia, the lexical approach, competency-based language teaching, taskbased language teaching (TBLT), and many others. How far it is possible to apply these methods and approaches to a specific foreign language teaching context, however, seems to be under-researched. The extent to which the classroom teacher can use these methods and approaches in his or her actual classroom teaching is, therefore, doubtful. The label most widely accepted in the "language teaching" world of today is "communicative language teaching" (CLT). CLT, for many scholars, is "an approach, not a method ... . It is a "broadly based theoretical position 
about the nature of language and language teaching and learning" (Brown, 2000: 266). It encompasses a diverse set of principles reflecting a communicative view of language and language learning" (Richards and Rodgers, 2003: 172; see also Hammer, 2005: 84-5). And like all other language teaching methods and approaches, CLT is a big word and is too general to be applied to a specific classroom context (like the foreign language classroom in Vietnam) which uses a specific set of textbooks (like the VEPH-Macmillan set of textbooks for grade 1 and grade 2) to fulfil the goal(s) of a specific curriculum (like the General School Education Introductory English Curriculum for Grade 1 and Grade 2 ). This suggests that our method of teaching a particular course/programme should be specific. It should take into consideration all the specific features such as the children's linguistic, psychological, and physiological characteristics; their economic, cultural, and environmental conditions; the goal of the Curriculum, the content of the textbooks, the use the children will make of their ability in English once they have acquired it, the amount of English knowledge and the level of English skills they are required to achieve, the length of the course and the teaching hours in the course, the length of a period/lesson, the qualification of the teachers and their institutional and professional constraints, the tests or examinations imposed, and many others. With these specificities mind, we now move on to outline some classroom methods of teaching English to Vietnamese grade 1 and grade 2 children. The outline is organized into two headings: teaching methods and teaching procedure.

\subsubsection{Teaching methods}

Children "love to imitate and mime; they are uninhibited by acting out roles, and they enjoy repetition because it gives them a sense of assurance and achievement. They are ready to accept the fact that other people do and say things differently without worrying about the reasons for the differences. They love an active situation where they can express themselves vocally and physically. They enjoy singing and playing, and doing as the teacher does" (Rivers, 1970: 362). This being so, a multiple method should be employed to teach English to grade 1 and grade 2 children, which can be generally captured in the following four terms: oral method, activity method, visual method and ostensive method.

1. The oral method (somewhat similar to the traditional aural-oral or audio-lingual method) is the first to be recommended here because language is primarily a spoken activity and letters and prints are abstract symbols representing it. There seems to be some transfer from learning the spoken word to learning reading and writing, but very little indeed the other way. The well-mastered, correctly learned spoken language will help both subsequent reading and writing (Rivers, 1970; see also O'Byrne, 1973). By the oral method is meant that listening and speaking are taught first listening, then speaking. Reading and writing will come in later. The linear order of listening - speaking - reading - writing, however, does not mean that these skills are taught separately one after another as suggested in a number language teaching methodology textbooks (e.g. Rivers, 1970; Richards and Rodgers, 2003; Harmer, 2005; Ur, 2012). Neither does it mean that the teaching of reading and writing in English should take place until a fluent oral foundation has been established as in the case of teaching the mother tongue or the first language. Rather it means that the four language skills of listening, speaking, reading, and writing should be taught either simultaneously in one and the same lesson, or in consecutive sequence in which listening and 
speaking may come in in the first lesson, and reading and writing in the next. It has become common that most of our children come to learn English with the expectation of speaking it and this expectation is intensely interested by their parents. If there were no other reasons but this, some effort should be made to give children successful oral start as a motivating factor. But surely our children cannot suddenly speak English without being given some oral language input. For them to be able to speak English, listening is the first skill that should be taught; and the first and normal step is that children receive the sounds - the main source of the language - through their ears (listen), and unlike the way they acquire the sounds of their mother tongue, after they hear the sounds of a foreign language they are required to repeat (speak) them.

The oral method can be used to teach the "Listen and repeat" activity effectively which is designed across the sixteen learning units in English 1 - Student's Book. It can also be effectively employed to teach chants, songs, and games. In English 1 - Student's Book, chants and songs are presented in lines. In teaching how to sing a chant or a song, the teacher first sings the chant or the song (word after word, then line after line) for the pupils to hear. Then she sings again and lets the pupils repeat the chant or the song in the same way as she did. Then she lets the pupils listen to the chant or the song either from her own performance or from the audio recording and say and repeat the chant or sing the song along in chorus until they can perform the task independently. Whatever criticism one may make about the drawback of the oral method, it still exists in the current FL classroom, and is still popular among EFL teachers and students all over the world. No one can speak another language without being taught in the oral method of one form or another. It is especially suitable for teaching young children as it encourages listening and repetition - activities that lead to oral fluency in English.

2. Children are physically active; "They love an active situation where they can express themselves vocally and physically" (Rivers, 1970: 362; see also Shin and Scrandall, 2015: 25). Here the activity method enters to be recommended. By the activity method is meant that language is best taught through activities, and verbal language (language contents and language skills) should be taught along with non-verbal language (body movement, facial expressions, gestures, mimes and actions). In English 1 - Student's Book, there are many activities for the teacher to employ the activity method effectively to teach his or her pupils: "Listen and repeat", "Point and say", "Listen and chant", "Listen and tick", "Trace", "Trace and then write", "draw and colour", "Let's talk", "Listen and tick" "Listen and match", "Find and circle", "Let's play (games such as "Simon says", "A happy circle", "Picture dominoes")". These activities are impressively presented and well woven throughout the book. They are fun, enjoyable, and natural to young children. Through these "learning and/ by doing" activities, children can absorb and learn the language effectively.

Children are ready to form small groups to do an activity together. The readiness with which they form groups and participate in team activities is a quality which lends itself to the English lesson. Not only does group work give children more chance to talk with each other but it harnesses the purposeful and instrumental use of English (Broughton et al., 1978: 170). The activity method is in line with these characteristics of children: it matches language processing with physical action (Asher, 1977; Harmer, 2005); it makes language learning more effective when it is fun (Larsen-Freeman, 2003); 
and, in particular, it sees language learning as an inter-subjective undertaking, focusing on the coparticipation of the teacher and his or her pupils, and of one pupil with other(s) of his or her peers (Breen and Candlin, 1980).

3. "Lack of aural stimulus is relatively easy to tolerate; even young learners will work for a while in silence without searching for something to listen to. This, however, is not true of the visual, which is a very dominant channel of input: so much so, that if young learners are not supplied with something to look at that is relevant to the learning task in hand they will find and probably be distracted by something that is not" (Ur, 2012: 289). This suggests that visual method should form part of the total range of methods of teaching English to young children. By the visual method is meant that the teacher employs visual materials to teach language. Visual materials are of various types. The most obvious type for children is the picture; and the more clearly visible, striking and colourful the better. The teacher is advised to use the pictures in professionally drawn pictures or paragraphs: those are in the textbook, or coloured posters, or pictures cut from magazines. For those classes that are computer-assisted, the teacher can display the pictures he or she has selected on the screen and help the pupils do the activity/task.

It is obvious that classroom conditions imposeastrictlimitonlivinglanguage situations, but the good teacher can seek to devise trueto-life situations for her pupils to experience authentic language in a contextualized way. Ways of devising situations may vary from the presentation of pictures, models to acting out a dialogue or a game. If, for instance, the teacher wants to teach school things, she may devise a school situation by making a large picture of a school in which pens, books, notebooks, erasers, school bags are presented. Or if the teacher wants to teach some foods and drinks, fish, chips, milk, and chicken can be selected to be taught by means of a picture of a "fish and chip" shop (see Unit 5, English 1 - Student's Book, Page 23).

4. It is generally agreed that in teaching a foreign language, one teaches meaning, not just form. The question of meaning is very complicated, and to teach young children a meaning in a language other than their own mother tongue may well be difficult for the foreign language teacher. To solve the problem, the teacher is advised to use a number of different strategies. In the early stage of English learning, she may say or explain in Vietnamese, or, when the language is short and simple, she may say in English first and then in Vietnamese. These teaching strategies may be faced with some impractical "theoretical objections", but in actual practice, they are quite effective considering the difficulty our young children of a foreign language meet when they hear the teacher says rubrics in English for the first time such as "Find the words.", "Write/ Trace the letters.", or "Listen and tick", or the long and complex explanation of how a game is played (which may be even beyond the teacher's English language proficiency) such as the game "Pass the ball" (Lesson 1, Unit 6, English 1 -Student's Book). Which language (English or Vietnamese) should the teacher use to explain the rules of the game to her pupils when in Vietnamese the explanation would be roughly like this: "Bây giờ chúng ta cùng nhau chơi một trò chơi nhé. Tên trò chơi là "Pass the ball". Cô có luật chơi như sau: Cô có một quả bóng. Khi cô bật nhạc, cô sẽ chuyền quả bóng cho một bạn. Bạn đó phải chuyền quả bóng tiếp cho bạn thứ hai. Bạn thứ hai phải chuyền quả bóng tiếp cho bạn thứ ba. Cứ thế đến khi nhạc dừng lại, bạn nào cầm bóng không chuyền cho bạn khác khi 
nhạc vẫn đang bật phải nói to một từ trong bốn từ chúng ta vừa học: bell, pen, pencil, hoặc red. Các con rõ chưa nào?" (Now let us play a game. The game is "Pass the ball". The rules of playing this game is as follows: I have a ball. When I turn on the music, I will pass the ball to one of you. The one who receives the ball from me will have to pass it to another friend (second friend). Then he or she will pass the ball to another friend (third friend). And so you will continue passing the ball until the music stops. Whoever fails to pass the ball when the music is on must say aloud one of the four words we have just learned: bell, pen, pencil, or red. Are your clear?).

Alternatively, in order to teach meaning, the teacher may use what is commonly referred to as the ostensive method (which shares some features with the visual method). By the ostensive method is meant that the teacher teaches meaning through perception. She may point to and name people, (toy) animals, or objects such as Bill, Ba, Sue, Phil, car, cat, cup, dog, etc.; or she may make a simple contrast between people, animals, or objects (e.g. short girls v. tall girls, big cars v. small cars, brown dogs v. black dogs, etc.); or she can teach English prepositions by actually moving an object from "in" to "on" or "over" some other objects (e.g. The dog is running in the room. The car is moving on the road. The man is jumping over the fence).

Ostensive tools such as gestures and actions (those that are nowadays generally subsumed under the umbrella term of TPR (Total Physical Response) actions (Asher, 1977) can also be used to teach meaning. In teaching pupils how to sing a song, for example, the teacher announces what she is doing at the moment she is doing it (she sings the song and performs actions and gestures along). Pupils listen to the teacher's singing and observe her accompanying actions and gestures. In due course, they will take over the actions and gestures and at the same time will use the appropriate language. The procedure can be repeated until the children can sing the song independently. In this way, the teacher can put the language which is to be learned into authentic context of use so that the pupils may "live the language" (Wallwork, 1972: 153): they can understand meaning through experiencing the situation and the language that occurs in the situation (cf. Halliday et. al., 1964). Apart from actions and gestures, the teacher can use flash cards, pictures, and various objects and realia to make the classroom come alive and resemble more closely to the real world outside.

Proper use of the oral method, activity method, visual method, and ostensive method can free the teacher to be more the observer and facilitator in the learning process and free the pupils to learn to use the language and learn to love the potentially fabulous experience of being able to communicate in another language with other people around - a vivid example of the "learner-centred approach" in foreign language teaching (cf. Nunan, 1991; Tudor, 1996).

\subsubsection{Teaching procedure}

The specific classroom methods outlined above cannot be effective without the teacher's exploitation of an appropriate teaching procedure. To date, there are a number of teaching procedures available in the second/ foreign language teaching literature. Apart from the classic tripartite procedure of P-P-P which stands for Presentation, Practice, and Production, there are at least four other alternatives: (1) the A-R-C procedure (Scrivener, 1994) which stands for Authentic use, Restricted use, and Clarification and focus, (2) the O-H-E procedure (Lewis, 2002 cited in Harmer, 2005) which stands for Observe, Hypothesize, and Experiment, 
(3) the I-I-I procedure (McCarthy and Carter, 1995) which stands for Illustration, Interaction, and Induction, and (4) the E-S-A procedure (Harmer, 2005, 2017) which stands for Engage, Study, and Activate (for more detail of the P-P-P procedure and its alternatives, see Harmer, 2005: 80-4). A close examination of these teaching procedures reveal that there is nothing wrong with any one of them; the only problem with them may be that they are too general to be applied to the teaching of an EFL lesson which consists of several separate activities/tasks each of which is intended to achieve a particular communicative goal. The procedure we are suggesting here is more practical and more detailed, aiming to help the teacher how to deliver a specific activity/task effectively: the G-I-P-O procedure which stands for Goal, Input, Procedure, and Outcome. Details of this procedure can be elaborated as follows:

The teaching of an activity begins with the teacher's setting a Goal for the activity. After the goal has been defined, the teacher moves on to the second step - specifying language Input (sounds, letters, words, including audio and visual materials) needed for teaching and learning the activity. Once the language input has been specified, the teacher moves on to the third step - the Procedure - where the teacher actually handles the teaching point of the activity which consists of a number of sub-steps (how many steps needed depends on the nature of a particular activity). The activity ends with the Outcome step where the teacher checks her pupils' achievement against the goal that has been set. If the goal is achieved, the teacher can move on to the next activity. Below is an example of how an activity can be taught, using the G-I-P-O procedure. The activity is Listen and repeat taken from Lesson 1, Unit 1, English 1 - Student's Book (Page 6).

\begin{tabular}{|l|l|}
\hline Goal: & $\begin{array}{l}\text { Pupils will be able to pronounce the sound of the letter } B / b \text { in isolation and in the } \\
\text { words ball, Bill, book, and bike correctly. }\end{array}$ \\
\hline Input: & $\begin{array}{l}\text { The teacher prepares input (both linguistic and audio and visual materials or realia) } \\
\text { for teaching the activity: She may use the context picture (on Page 6), or she may } \\
\text { enlarge the picture, make flashcards which contain both the upper case letter } B \text { and } \\
\text { the lower case letter } b \text {, highlight them (either in bold or in colour) in the words ball, } \\
\text { Bill, book, and bike, etc. }\end{array}$ \\
\hline Procedure: & $\begin{array}{l}\text { The teacher can break the procedure down into the } \\
\text { following steps: } \\
\text { Step 1: the teacher has pupils look at the picture (saying } \\
\text { Look at the picture, please!). Then she draws pupils } \\
\text { attention to the two modes of letter } B / b \text {, the word next to } \\
\text { the ball and other words next to the things, and the colour } \\
\text { of the letter } B / b . \\
\text { Step 2: the teacher asks pupils to point to the letter } B / b . \\
\text { Then she plays the recording for them to hear and repeat } \\
\text { the sound of the letter } B / b \text { (saying Listen and repeat, } \\
\text { please!). (She can repeat the procedure, if necessary). }\end{array}$ \\
\hline
\end{tabular}




\begin{tabular}{|l|l|}
\hline & $\begin{array}{l}\text { Step 3: the teacher then asks pupils to point to the ball and then to the word ball (saying Point to } \\
\text { the ball and the word "ball" please). Then she asks them to listen and repeat the word, (saying } \\
\text { Listen and repeat the word "ball", please!) } \\
\text { Step 4: the teacher repeats the same procedure with the words Bill, book, and bike. While } \\
\text { the pupils practise, the teacher can give further support to them, especially to those pupils } \\
\text { who find it difficult to do the task. } \\
\text { Step 5: the teacher plays the recording again and asks the pupils to listen, point to the letter } \\
\text { B/b and the word Bill, book and bike and repeat until they can perform the task effectively. } \\
\text { Step 6: the teacher calls some pupils to pronounce the sound /b/ of the letter B/b in isolation } \\
\text { and in the words ball, Bill, book and bike in front of the class (praising Well done! when the } \\
\text { pupils perform the task well). }\end{array}$ \\
\hline $\begin{array}{l}\text { When the pupils can pronounce correctly the sound of the letter B/b in isolation and } \\
\text { in the words Bill, ball, bike and book, the teacher can move on to the next activity } \\
\text { (saying Well done! Now we move on to the next activity.). }\end{array}$ \\
\hline
\end{tabular}

\section{Conclusion}

This paper has been concerned with the new General School Education Introductory English Curriculum for Grade 1 and Grade 2 promulgated by MoET in 2018. We claimed that the Curriculum is a new innovation in foreign language general school education in Vietnam because, as far as we know, although it is an optional curriculum, it is issued at the national level; no other foreign language curricula of similar kind have ever been issued at national level like this one in Vietnam. To highlight the innovation, we have explored some of the most prominent aspects of the Curriculum: the characteristics of the Curriculum, the principles for designing the Curriculum, the goal and objectives of the Curriculum, and the content of the Curriculum. Then we moved on to present in some detail the new set of English textbooks for Vietnamese grade 1 and grade 2 children developed by VEPH in collaboration with Springer Nature Macmillan Education, looking specifically at Tiếng Anh 1 (English 1) which includes Student's Book, Teacher's Book, and Workbook. It can be seen that the general approach to developing the textbook is for communication. It is designed around sixteen learning units, four fun time sections, and four review units. Each learning unit is the centre around which language components (phonics/sounds, vocabulary, structures) and communication-based activities such as "Look, listen and repeat", "Listen and chant", "Let's chant", "Let's sing", etc., are organized. These language components and activities are integrated into the fabric of the lessons to facilitate pupils' development of listening, speaking, reading, and writing in English.

Realizing that without a classroomspecific teaching methodology and a proper teaching procedure, the teaching of English as a foreign language to children would cease to be ineffective, we have suggested four specific methods and a procedure for teaching an activity which we thought would stand benefit to the primary teacher of English: the oral method, the activity method, the visual method, and the ostensive method, and the G-I-P-O procedure. It should be noted at this point that although these teaching methods and the teaching procedure are beneficial to the teacher, they are only an artificial breaking up of what is actually an organic process from the beginning to the end of the lesson or activity. When it comes to actual teaching, much more should be done on the part of the teacher to make the lesson or the activity more enjoyable and effective.

It may be argued that the methods we have 
suggested favour imitation - pupils learn by imitating the teacher, using language. This is true since the actual classroom is only a small piece of the world in which we expect our children to use English, artificial means must be used to transform it into a variety of other pieces, and the obvious means for performing this transformation are "listening and repeating bits of the language", "listening, repeating and singing songs", and "listening, repeating, and singing chants". These have always been useful educational or teaching devices for children at the early stage of learning. By creating a variety of situations in the classroom - in part by letting pupils listen to and repeat the English sounds and then by letting them relabel or rename things/objects and people and relate them to the symbols (letters and words), but also in part by simply helping them act out small dialogues, sing simple songs and simple chants, and play simple language games as a class or in groups (supplemented by realia if desired) - the teacher can expand the classroom indefinitely, provide natural contexts for the language being used, and prepare her pupils for real communication.

The prominent features of the Curriculum and the textbooks we have presented, and the classroom methods of teaching we have suggested in this paper, no matter how important they are, are only three factors contributing to the success of the Curriculum. For the Curriculum to be effectively implemented, the following problems derived from the nature of the Curriculum itself should be solved:

First, because English is an optional subject, many primary schools do not find the need to organize the programme.

Secondly, because English is an optional subject, it is not tuition-free; many people tend to think that it is only suitable for schools in urban and affluent areas.

Thirdly, because the Curriculum is a new one, there will certainly be a shortage of teachers.

Fourthly, because English is an optional subject, it will be very difficult for schools to recruit qualified teachers.

And finally, because English is an optional subject and there is very little class time allocated to it, schools are not allowed to recruit teachers on a permanent basis. The result is that the teachers recruited will feel unassured of their work. This, combined with the poor salary they receive, will result in the ineffectiveness of the Curriculum, opening the success of the innovation to questions.

\section{References}

\section{Vietnamese}

Bộ Giáo dục và Đào tạo [MOET] (2010a). Chương trình tiếng Anh thi điềm tiểu học (Pilot English Curriculum for Primary Schools in Vietnam) ban hành theo Quyết định số 3321/QĐ-BGDĐT ngày 12 tháng 8 năm 2010 của Bộ trưởng Bộ Giáo dục và Đào tạo.

Bộ Giáo dục và Đào tạo [MoET] (2010b). Quyết định số 4674/QĐ-BGDĐT ngày 5 tháng 10 năm 2010 của Bộ truởng Bộ Giáo duc và Đào tạo về việc triển khai Chưong trình thi điểm tiếng Anh tiểu học (Decision on the Implementation of the Pilot English Curriculum for Primary Schools in Vietnam).

Bộ Giáo dục và Đào tạo [MoET] (2012a). Chuoong trình giáo duc phổ thông môn tiếng Anh thi điềm cấp trung hoc co sơ (Pilot English Curriculum for Lower Secondary Schools in Vietnam) ban hành theo Quyết định số 01/QĐ-BGDĐT ngày 03 tháng 01 năm 2012 của Bộ trưởng Bộ Giáo dục và Đào tạo.

Bộ Giáo dục và Đào tạo [MoET] (2012b). Chưong trình giáo duc phổ thông môn tiếng Anh thi điểm cấp trung hoc phổ thông (Pilot English Curriculum for Upper Secondary Schools in Vietnam) ban hành theo Quyết định số 5290/QĐ-BGDĐT ngày 23 tháng 11 năm 2012 của Bộ trưởng Bộ Giáo dục và Đào tạo.

Bộ Giáo dục và Đào tạo [MoET] (2012c). Quyết định số 3456/QĐ-BGDĐT ngày 05 tháng 9 năm 2012 vè việc triên khai Chuoong trình giáo dục phổ thông môn tiếng Anh thi điểm cấp trung hoc cơ sở (Decision on the Implementation of the Pilot English Curriculum for Lower Secondary Schools in Vietnam).

Bộ Giáo dục và Đào tạo [MoET] (2013). Quyết định số 3702/QĐ-BGDĐT ngày 10 tháng 9 năm 2013 về việc triển khai Chuoong trình giáo duc phổ thông môn tiếng Anh thi điểm cấp trung học phô thông (Decision on the Implementation of the Pilot English Curriculum for Upper Secondary Schools in Vietnam).

Bộ Giáo dục và Đào tạo [MoET] (2018a). Chuoong trình giáo dục phổ thông: Chưong trình tông thể (General School Education Curriculum) ban hành kèm theo Thông tư số 32/2018/TT-BGĐT ngày 26 tháng 12 
năm 2018 của Bộ trưởng Bộ Giáo dục và Đào tạo.

Bộ Giáo dục và Đào tạo [MoET] (2018b). Chuong trình giáo dục phổ thông môn tiếng Anh (General School Education English Curriculum) ban hành kèm theo Thông tư số 32/2018/TT-BGDĐT ngày 26 tháng 12 của Bộ trưởng Giáo dục và Đào tạo.

Bộ Giáo dục và Đào tạo [MoET] (2018c). Chuoong trình giáo duc phổ thông làm quen tiếng Anh lớp 1 và lớp 2 (General School Education Introductory English Curriculum for Grade 1 and Grade 2) ban hành kèm theo Thông tư số 32/2018/TT-BGDĐT ngày 26 tháng 12 năm 2018 của Bộ trưởng Bộ Giáo dục và Đào tạo.

Hoàng Văn Vân (2016). Vai trò và vị thế của tiếng Anh trong thời kì hội nhập và một số hàm ý cho việc hoạch định chính sách ngoại ngữ ở Việt Nam (The role and status of English in the period of international integration and some implications for foreign language policy making in Vietnam). $V N U$ Journal of Science: Foreign Studies, 46, 12-27.

Hoàng Văn Vân (2019). Giáo dục ngoại ngữ ở bậc phổ thông trên thế giới: Tình hình hiện tại và những vấn đề. VNU Journal of Foreign Studies, 35(5), 1-40.

Hoàng Văn Vân et al., (2019a). Tiếng Anh 1 - Sách học sinh (English 1 - Student's Book). Hà Nội: Nhà xuất bản Giáo dục Việt Nam.

Hoàng Văn Vân et al., (2019b). Tiếng Anh 1 - Sách giáo viên (English 1 - Teacher's Book). Hà Nội: Nhà xuất bản Giáo dục Việt Nam.

Hoàng Văn Vân et al., (2019c). Tiếng Anh 1 - Sách bài tập (English 1 - Workbook). Hà Nội: Nhà xuất bản Giáo dục Việt Nam.

Nhà xuất bản Giáo dục Việt Nam (Vietnam National Publishing House). sachmem.vn.

\section{English}

Asher, J. (1977). Learning Another Language Through Actions: The Complete Teacher's Guide Book. Los Gatos, Calif.: Sky Oaks Production.

Breen, M.P. and Candlin, C.N. (1980). The Essentials of a Communicative Curriculum in Language Teaching. Applied Linguistics, 1(2), 89-112.

Broughton, G. et al. (1978). Teaching English as a Foreign Language. London, Henley and Boston: Routledge \& Kegan Paul.

Brown, H.D. (2000). Principles of Language Learning and Teaching. New York: Pearson.

Cameron, L. (2011). Teaching Languages to Young Learners. Cambridge: Cambridge University Press.

Cheshire, J. (1996). Introduction: Sociolinguistics and English around the World. (In) English around the World: Sociolinguistic Perspectives, pp. 1-12. Cheshire, J. (Ed.). Cambridge: Cambridge University Press.

Eurydice (2005). Key Data on Teaching Languages at School in Europe. 2005 edition. Brussels: Eurydice.

Eurydice (2017). Eurydice Report: Key Data on Teaching Languages at School. Retrieved 18 Feb. 2018 from https://www.csee-etuce.org/en/news/archive/2038eurydice-report-key-data-on-teaching-languagesatschool-in-europe
Fernández, E.M. and Cairns, H.S. (2015). Fundamentals of Psycholinguistics. Singapore: Wiley-Blackwell.

Halliday, M.A.K. (2017). Written Language, Standard Language, Global Language. (In) Halliday in the 21st Century, pp. 87-103. Webster, J.J. (Ed.). London: Bloomsbury.

Halliday, M.A.K., McIntosh, A., and Strevens, P.D. (1964). The Linguistic Sciences and Language Teaching. London: Longmans.

Harmer, J. (2005). The Practice of English Language Teaching. Third Edition. Malaysia: Longman.

Harmer, J. (2017). How to Teach English. New Edition. Thirteenth Impression. England: Pearson Education Limited.

Hoang, V. V. (2012). The Role of Textbooks in the Implementation of the National Project "Teaching and Learning Foreign Languages in the National Education System Period 2008-2020". VNU Journal of Science: Foreign Studies, 30, 75-89.

Hoang, V.V. (2018). MoET's Three Pilot English Language Communicational Curricula for Schools in Vietnam: Rationale, Design and Implementation. VNU Journal of Foreign Studies, 34(2), 1-25.

Kachru, B.B. (1985). Standards, Codification and Sociolinguistic Realism: The English Language in the Outer Circle. (In) English in the World: Teaching and Learning the Language and Literatures, pp. 11-30. Quirk, R. and Widdowson, H.G. (Eds.). Cambridge: Cambridge University Press and the British Council.

Larsen-Freeman, D. (2003). Techniques and Principles in Language Teaching. Second Edition. Seventeenth Impression. Oxford; Oxford University Press.

Lenneberg, E.H. (1967). Biological Foundations of Language. New York: Wiley.

Lewis, M. (2002). The Lexical Approach: The State of ELT and a Way Forward (Language Teaching Publications). First Edition. Heinly ELT.

Littlewood, W. (1999). Communicative Language Teaching. Cambridge: Cambridge University Press.

McCarthy, M. and Carter, R. (1995). Spoken Grammar: What is it and How can We Teach it? ELT Journal $49 / 3$.

Moon, J. (2005). Children Learning English. A Guidebook for English Language Teachers. Thailand: Macmillan Education.

Nunan, D. (1991). The Learner-Centred Curriculum. Fourth Printing. Cambridge: Cambridge University Press.

Nunan, D. (2003). The Impact of English as a Global Language on Educational Policies and Practices in the Asia-Pacific Regions. TESOL QUARTERLY, 37(4) 4.

O'Byrne, V. de R. (1973). Curriculum Planning for Modern Languages. (In) The Teacher's Role in Curriculum Design, pp. 145-70. Hughes, P. (Ed.). Sydney: Angus and Roberton Publishers.

O’Neill, R. (1995). Why Use Textbooks? (In) Current Change in English Language Teaching, pp. 148-56. Oxford: Oxford University Press.

Pew Research Center (2015). Learning a Foreign 
Language a 'must' in Europe, not so in America. Retrieved 22 Feb. 2019 from http://www.pewresearch. org/fact-tank/2015/07/13/learning-a-foreignlanguagea-must-in-europe-not-so-in-america/

Richards, J.C. (2001). Curriculum Development in Language Teaching. Cambridge: Cambridge University Press.

Richards, J.C. and Rodgers, T.S. (2003). Approaches and Methods in Language Teaching. $6^{\text {th }}$ Printing. Cambridge: Cambridge University Press.

Rixon, S. and Papp, S. (2018). The Educational Contexts of the Teaching of English to Young Learners and the Roles of Assessment. (In) Studies in Language Testing 74, pp. 18-69. Cambridge: Cambridge University Press.

Rivers, W. M. (1970). Teaching Foreign Language Skills. Third Impression. Chicago and London: The University of Chicago Press.

Scott, W.A. and Ytreberg, L.H. (2011). Teaching English to Children. Malaysia: Longman.

Scrivener, J. (1994). PPP and after. The Teacher Trainer $8 / 1$.
Scrivener, J. (2009). Learning Teaching: A Guide Book for English Language Teachers. Second Edition. Oxford: MacMillan.

Shin, J.K. and Scrandall, J.J. (2015). Teaching Young Learners English: From Theory to Practice. Singapore: Heinle.

Stern, H.H. (1967). Foreign Languages in Primary Education: The Teaching of Foreign or Second Languages to Young Learners. Oxford: Oxford University Press.

Tudor, I. (1996). Learner-centredness as Language Education. Cambridge: Cambridge University Press.

Ur, P. (2012). A Course in Language Teaching. Cambridge: Cambridge University Press.

Wallwork, J.F. (1972). Language and Linguistics. London: Heinemann.

Wilkins, D.A. (1976). Notional Syllabuses. London: Oxford University Press.

\title{
“CHƯƠNG TRÌNH GIÁO DỤC PHỔ THÔNG LÀM QUEN TIẾNG ANH LỚP 1 VÀ LỚP 2": ĐIỂM CÁCH TÂN TRONG GIÁO DỤC NGOẠI NGŨ Ở TRƯỜNG PHỔ THÔNG VIỆT NAM
}

\author{
Hoàng Văn Vân \\ Trung tâm Nghiên cúu giáo dục ngoại ngũu, ngôn ngũu và quốc tế học, \\ Truờng Đại hoc Ngoại ngũu, ĐHQGHN, \\ Phạm Văn Đồng, Cầu Giấy, Hà Nội, Việt Nam
}

Tóm tắt: Bài viết này liên quan đến một điểm cách tân quan trọng trong giáo dục ngoại ngữ ở bậc phổ thông Việt Nam đã và đang thu hút sự quan tâm đáng kể của các nhà giáo dục ngoại ngữ, các giáo viên ngoại ngữ, và công chúng - Chuơng trình giáo duc phổ thông làm quen tiếng Anh lớp 1 và lớp 2 được Bộ Giáo dục và Đào tạo ban hành năm 2018. Để làm nổi bật điểm cách tân quan trọng này, bài viết dự định giải quyết ba vấn đề chính sau đây: (1) bài viết sẽ nghiên cứu và làm rõ một số khía cạnh quan trọng nhất của Chuơng trình giáo duc phổ thông làm quen tiếng Anh lớp 1 và lớp 2; (2) bài viết sẽ trình bày và thảo luận chi tiết các nội dung của Tiếng Anh 1 - một bộ sách giáo khoa tiếng Anh mới được Nhà xuất bản Giáo dục Việt Nam phối hợp với Nhà xuất bản Macmillan Education thuộc tập đoàn Springer Nature biên soạn theo Chuơng trình giáo dục phổ thông làm quen tiếng Anh lớp 1 và lớp 2; và (3) bài viết sẽ sơ thảo và thảo luận một số phương pháp dạy học cụ thể trên lớp và trình bày một quy trình lên lớp mới để dạy một hoạt động / nhiệm vụ nhằm giúp giáo viên và học sinh dạy và học tiếng Anh có hiệu quả.

Tù khoá: Chuoong trình giáo dục phổ thông làm quen tiếng Anh lớp 1 và lớp 2, bộ sách giáo khoa Tiếng Anh 1, các phương pháp dạy học tiếng Anh trên lớp có hiệu quả, quy trình mới để dạy một hoạt động ngôn ngữ 